\title{
Synthesis and Evaluation on Anticonvulsant and Antidepressant Activities of Naphthoquinone Derivatives Containing Pyrazole and Pyrimidine Fragments
}

\section{Nataliia Polish, ${ }^{1}$ Mariia Nesterkina,,${ }^{2,}$ Nataliia Marintsova, ${ }^{1}$ Andriy Karkhut, ${ }^{1}$ Iryna Kravchenko, ${ }^{2}$ Volodymyr Novikov ${ }^{1}$ and Andrei Khairulin ${ }^{3}$}

${ }^{1}$ Department of Technology Biologically Compounds, Pharmacy and Biotechnology, Lviv Polytechnic National University, Lviv 79013, Ukraine

${ }^{2}$ Department of Organic and Pharmaceutical Technology, Odessa National Polytechnic University, Odessa 65044, Ukraine

${ }^{3}$ Laboratory of Condensed Heterocyclic Compounds, Department of Sulfur Chemistry, Institute of Organic Chemistry NAS of Ukraine, Kyiv 02660, Ukraine

*Corresponding author: E-mail: mashaneutron@gmail.com; ORCID 0000-0002-3201-7961

Received: 02-22-2020

\begin{abstract}
Novel heterocyclic dichloronaphthoquinone derivatives have been synthesized by chlorine atom substitution in 2,3-dichloro-1,4-naphthoquinone to pyrazole or pyrimidine fragments. The structures of these compounds have been confirmed by FT-IR, ESI-MS, ${ }^{1} \mathrm{H}-\mathrm{NMR},{ }^{13} \mathrm{C}-\mathrm{NMR}$ and elementary analysis. Synthesized compounds were evaluated for their anticonvulsant action in a pentylenetetrazole (PTZ)-convulsion model and antidepressant activity in the forced swimming test (FST). All naphthoquinone derivatives at a dose $100 \mathrm{mg} / \mathrm{kg}$ indicated anticonvulsant effect in PTZ-induced test at $3 \mathrm{~h}$ and $24 \mathrm{~h}$ after oral administration. In addition, these compounds possessed prolonged antidepressant properties significantly reducing the duration of immobility time when compared to the reference drug amitriptyline.
\end{abstract}

Keywords: 2,3-dichloro-1,4-naphthoquinone; pyrazole and pyrimidine fragments; anticonvulsant activity; antidepressant action

\section{Introduction}

The development of novel compounds possessing combined action on central nervous system (CNS) and, thus, capable of being used simultaneously in treatment of various CNS disorders, still remains an active field in drug discovery. Such CNS disease state as depression is concomitant pathology in patients with epilepsy while some antidepressants were found to increase the risk of seizures (bupropion) or exhibit both the anticonvulsant and proconvulsant effect in experimental study (venlafaxine). ${ }^{1}$ In this context, synthesis of compounds contemporaneously demonstrating antidepressant and anticonvulsant activity is feasible approach to reduce aforementioned side effects. In this context, significant interest is attracted by naphthoquinones and their derivatives as building blocks for rational drug design. A considerable amount of these com- pounds have already been reported as antifungal, anti-inflammatory, anticancer and antibacterial agents. ${ }^{2-6}$ Surprisingly, only a limited number of publications are devoted to investigation of naphthoquinones influence on CNS. For example, amide derivatives of 4-amino-1,2-naphthoquinone were examined for anticonvulsant activity by the maximal electroshock (MES) and subcutaneous pentylenetetrazole (sc. PTZ) tests. ${ }^{7}$ The antidepressant potential of plumbagin, a medicinal plant-derived naphthoquinone, was explored in unstressed and stressed mice and explained by inhibition of brain monoamine oxidase A (MAO-A) activity. ${ }^{8}$ Naphthoquinones derived from Lithospermum erythrorhizon (acetylshikonin and shikonin) were isolated and proven as inhibitors of MAO-A and $\mathrm{MAO}-\mathrm{B}$ in a competitive manner that might be further used in the treatment of depression. ${ }^{9}$ Obviously, the nature and position of substituents in naphthoquinone core are 
the crucial factors affecting the pharmacological evaluation of the structures. Bearing in mind that five- and six-membered heterocycles, pyrazole and pyrimidine, are important scaffold for CNS-active compounds, ${ }^{10-13}$ our attention was paid to the naphthoquinones containing these moieties. Thus, here we report the synthesis of aminopyrazole- and aminopyrimidine derivatives of 2,3-dichloro-1,4-naphthoquinone and their anticonvulsant and antidepressant activity determined by pentylenetetrazole (PTZ) and forced swim test (FST), accordingly.

\section{Experimental}

\section{1. Chemistry}

IR spectrum was measured with a Thermo Scientific Nicolet iS10 FT-IR Spectrometer using Nicolet iZ10 module (Thermo Fisher Scientific, Madison, WI, USA) equipped with a diamond window in a range of 4000-525 $\mathrm{cm}^{-1}$. ${ }^{1} \mathrm{H} \mathrm{NMR}$ and ${ }^{13} \mathrm{C}$ NMR spectra were recorded on Varian Mercury-400 (Varian Inc., Palo Alto, CA) 300 $\mathrm{MHz} / 75 \mathrm{MHz}$ spectrometer with DMSO- $d_{6}$ or $\mathrm{CDCl}_{3}$ as solvents and TMS as an internal standard; the coupling constants are given in $\mathrm{Hz}$. The elemental analysis was performed on a Euro Vector EA-3000 (Eurovector SPA, Redavalle, Italy) microanalyzer. Elemental analyses were within $\pm 0.4 \%$ of the theoretical values. Electrospray ionization mass spectrometry (ESI-MS) was measured by Agilent 1100 Series (LC/MSD Trap) Spectrometer applying isocratic elution of acetonitrile : $0.01 \%$ formic acid aqueous solution (70:30). Separation column: Rapid Resolutionn HT Cartige 4.6x30 mm, 1.8-Micron, Zorbax SB-C18. Melting points (uncorrected) were measured in an open capillary tube using a Stuart SMP30 melting point apparatus.

\section{1. 1. General Procedure for the Synthesis of Aminopyrazole Derivatives of Naphthoquinone (3a-d)}

To a magnetically stirred solution of 2,3-dichloro-1,4-naphthoquinone (1) $(0.68 \mathrm{~g}, 0.3 \mathrm{mmol})$ in ethanol $(50 \mathrm{~mL})$ was added a solution of aminopyrazole $\mathbf{2 a - d}$ $(0.3 \mathrm{mmol})$ in ethanol $(20 \mathrm{~mL})$. The reaction was carried out at $78{ }^{\circ} \mathrm{C}$ in the presence of an equivalent amount of $\mathrm{Na}_{2} \mathrm{CO}_{3}$ with constant stirring for $3 \mathrm{~h}$. Reaction progress was monitored by TLC analysis. After reaction completion the obtained precipitate was filtered, washed several times with water and dried. The precipitate was suspended in 20 $\mathrm{ml}$ of ethanol, heated to boiling, filtered from impurities, the filtrate was cooled with ice to $0{ }^{\circ} \mathrm{C}$, the precipitated crystals were filtered, dried in vacuum over $\mathrm{CaCl}_{2}$ to afford compounds $\mathbf{3} \mathbf{a}-\mathbf{c}$ as red and $\mathbf{3 d}$ as orange colored crystals.

2-Chloro-3-((1-(difluoromethyl)-1-H-pyrazol-3-yl)amino)-naphthalene-1,4-dione (3a)

Yield $42 \%$, red crystals, m.p. $=123-125^{\circ} \mathrm{C}$. IR $\left(\mathrm{KBr}, \mathrm{cm}^{-1}\right)$ :
$3642(\mathrm{~N}-\mathrm{H}), 2968,2895\left(\mathrm{CH}_{\text {aliphatic }}\right), 1681(\mathrm{C}=\mathrm{O}), 1059$, $1083(\mathrm{C}-\mathrm{F}) .{ }^{1} \mathrm{H}$ NMR $\left(300 \mathrm{MHz}, \mathrm{DMSO}-d_{6}\right): \delta 9.01(\mathrm{~s}, 1 \mathrm{H}$, $\mathrm{NH}), 7.93-8.05(\mathrm{~m}, 4 \mathrm{H}, \mathrm{Ar}-\mathrm{H}), 7.12(\mathrm{~d}, J=4.4 \mathrm{~Hz}, 1 \mathrm{H}$, CH-pyraz.), 5.95 (d, $J=4.4 \mathrm{~Hz}, 1 \mathrm{H}, \mathrm{CH}$-pyraz.), 6.63 (s, $1 \mathrm{H}, \mathrm{CH}) .{ }^{13} \mathrm{C}$ NMR $\left(75 \mathrm{~Hz}, \mathrm{DMSO}-d_{6}\right) \delta$, ppm: $180.03(\mathrm{C})$, $176.9(\mathrm{C}), 149.1(\mathrm{C}), 147.9(\mathrm{C}), 133.1(\mathrm{CH}), 133.2(\mathrm{CH})$, $131.0(\mathrm{CH}), 130.6(\mathrm{C}), 129.1(\mathrm{C}), 123.9(\mathrm{CH}), 123.8(\mathrm{CH})$, $114.7(\mathrm{CH}), 106.1(\mathrm{C}), 94.8(\mathrm{CH})$. MS (ESI), $\mathrm{m} / z(\%)$ : calculated for $\mathrm{C}_{14} \mathrm{H}_{8} \mathrm{ClF}_{2} \mathrm{~N}_{3} \mathrm{O}_{2}[\mathrm{M}]^{+} 323$, found 323 (100). Calcd: C 58.45; H 3.50; Cl 12.32; N 14.61; O 11.12. Found: C 58.32; H 3.40; Cl 12.24; N 14.50. HPLC: $\mathrm{t}_{\mathrm{r}}=0.879 \mathrm{~min}$.

2-Chloro-3-((1-methyl-1H-pyrazol-3-yl)amino)naphthalene-1,4-dione (3b)

Yield 78\%, red crystals, m.p. $=215-217^{\circ} \mathrm{C}$. IR $\left(\mathrm{KBr}, \mathrm{cm}^{-1}\right)$ : $3200(\mathrm{~N}-\mathrm{H}) ; 1680,1652(\mathrm{C}=\mathrm{O}), 2967,2894\left(\mathrm{CH}_{\text {aliphatic }}\right), 717$ (C-Cl). ${ }^{1} \mathrm{H}$ NMR $\left(300 \mathrm{MHz}, \mathrm{CDCl}_{3}\right): \delta 9.03(\mathrm{~s}, 1 \mathrm{H}, \mathrm{NH})$, 7.96-8.07 (m, 2H, Ar-H), 7.71-7.91 (m, 2H, Ar-H), 7.60 (d, J $=2.2 \mathrm{~Hz}, 1 \mathrm{H}, \mathrm{CH}$-pyraz.), 6.04 (d, J=2.2 Hz, $1 \mathrm{H}, \mathrm{CH}$-pyraz.), $3.76\left(\mathrm{~s}, 3 \mathrm{H}, \mathrm{CH}_{3}\right) .{ }^{13} \mathrm{C}$ NMR $\left(75 \mathrm{MHz}, \mathrm{DMSO}-d_{6}\right) \delta$, ppm: $180.1(\mathrm{C}), 177.1(\mathrm{C}), 149.2(\mathrm{C}), 147.5(\mathrm{C}), 133.3(\mathrm{CH}), 133.2$ $(\mathrm{CH}), 132.2(\mathrm{CH}), 131.2(\mathrm{C}), 130.8(\mathrm{C}), 125.0(\mathrm{CH}), 124.8$ (CH), $106.7(\mathrm{C}), 92.7(\mathrm{CH}), 37.7\left(\mathrm{CH}_{3}\right)$. MS (ESI), $\mathrm{m} / z(\%)$ : calculated for $\mathrm{C}_{14} \mathrm{H}_{10} \mathrm{ClN}_{3} \mathrm{O}_{2}[\mathrm{M}]^{+}$287, found 287 (100). Calcd: C 58.45; H 3.50; Cl 12.32; N 14.61; O 11.12. Found: C 58.30; H 3.42; $\mathrm{Cl} 12.21 ; \mathrm{N} 14.50$. HPLC: $\mathrm{t}_{\mathrm{r}}=0.961 \mathrm{~min}$.

2-Chloro-3-((3-(p-tolyl)-1H-pyrazol-5-yl)amino)naphthalene-1,4-dione (3c)

Yield $56 \%$, red crystals, m.p. $=238-240{ }^{\circ} \mathrm{C}$. IR $\left(\mathrm{KBr}, \mathrm{cm}^{-1}\right)$ : $3500(\mathrm{~N}-\mathrm{H}), 1672(\mathrm{C}=\mathrm{O}), 1600-1572(\mathrm{C}=\mathrm{C}), 720(\mathrm{C}-\mathrm{Cl})$. ${ }^{1} \mathrm{H}$ NMR $\left(300 \mathrm{MHz}, \mathrm{DMSO}-d_{6}\right): \delta 12.95(\mathrm{~s}, 1 \mathrm{H}, \mathrm{NH}), 9.07$ (s, 1H, NH), 7.97-8.06 (m, 2H, Ar-H), $7.86(\mathrm{t}, 1 \mathrm{H}, \mathrm{Ar}-\mathrm{H})$, 7.79 (t, $1 \mathrm{H}, \mathrm{Ar}-\mathrm{H}), 7.63$ (d, J = 7.8 Hz, 2H, Ar-H), 7.26 (d, $J=7.9 \mathrm{~Hz}, 2 \mathrm{H}, \mathrm{Ar}-\mathrm{H}), 6.49$ (s, 1H, CH-pyraz.), 2.33 (s, 3H, $\left.\mathrm{CH}_{3}\right) .{ }^{13} \mathrm{C}$ NMR $\left(75 \mathrm{MHz}, \mathrm{DMSO}-d_{6}\right) \delta$, ppm: $179.9(\mathrm{C})$, $176.8(\mathrm{C}), 148.2(\mathrm{C}), 144.3(\mathrm{C}), 142.1(\mathrm{C}), 138.1(\mathrm{C}), 132.9$ $(\mathrm{CH}), 132.8(\mathrm{CH}), 131.2(\mathrm{C}), 131.1(\mathrm{C}), 129.8(2 \mathrm{CH}), 125.9$ $(2 \mathrm{CH}), 125.6(\mathrm{CH}), 125.2(\mathrm{CH}), 124.9(\mathrm{C}), 105.3(\mathrm{C}), 94.2$ $(\mathrm{CH}), 22.0\left(\mathrm{CH}_{3}\right)$. MS (ESI), $m / z(\%)$ : calculated for $\mathrm{C}_{20} \mathrm{H}-$ ${ }_{14} \mathrm{ClN}_{3} \mathrm{O}_{2}[\mathrm{M}]^{+}$363, found 363 (100). Calcd: C 66.03; H 3.88; $\mathrm{Cl}$ 9.74; N 11.55; O 8.80. Found: C 65.62; $\mathrm{H} \mathrm{3.77;} \mathrm{Cl}$ 9.63; N 11.25. HPLC: $\mathrm{t}_{\mathrm{r}}=1.389 \mathrm{~min}$.

Ethyl-4-((3-chloro-1,4-dioxo-1,4-dihydronaphthalen-2yl)amino)-1-phenyl-1H-pyrazol-3-carboxylate (3d)

Yield $76 \%$, orange crystals, m.p. $=162-165^{\circ} \mathrm{C}$. IR $\left(\mathrm{KBr}, \mathrm{cm}^{-}\right.$ $\left.{ }^{1}\right): 3300(\mathrm{~N}-\mathrm{H}), 1712(\mathrm{C}=\mathrm{O}), 1676,1652(\mathrm{C}=\mathrm{O}), 1604-1576$ $(\mathrm{C}=\mathrm{C}), 720(\mathrm{C}-\mathrm{Cl}) .{ }^{1} \mathrm{H}$ NMR $\left(300 \mathrm{MHz}, \mathrm{DMSO}-d_{6}\right): \delta 9.38$ (br.s, 1H, NH), 8.12 (s, 1H, CH-pyraz.), 8.01 (t, 2H, Ar-H), $7.89(\mathrm{~d}, J=7.4 \times 2 \mathrm{~Hz}, 1 \mathrm{H}, \operatorname{Ar}-\mathrm{H}), 7.82(\mathrm{~d}, J=7.4 \times 2 \mathrm{~Hz}, 1 \mathrm{H}$, Ar-H), 7.66 (d, J=7.9 Hz, 2H, Ar-H), $7.51(\mathrm{t}, 2 \mathrm{H}, \mathrm{Ar}-\mathrm{H}), 7.42$ (t, $1 \mathrm{H}, \mathrm{Ar}-\mathrm{H}), 4.04\left(\mathrm{q}, \mathrm{CH}_{2} \mathrm{CH}_{3}, 2 \mathrm{H}\right), 1.02\left(\mathrm{t}, \mathrm{CH}_{2} \mathrm{CH}_{3}, 3 \mathrm{H}\right)$. ${ }^{13} \mathrm{C}$ NMR $\left(75 \mathrm{MHz}\right.$, DMSO- $\left.d_{6}\right) \delta$, ppm: $180.2(\mathrm{C}), 176.9(\mathrm{C})$, $161.9(\mathrm{C}), 149.3(\mathrm{C}), 147.5(\mathrm{C}), 140.9(\mathrm{C}), 133.2(\mathrm{CH}), 133.1$ $(\mathrm{CH}), 131.1(\mathrm{C}), 131.0(\mathrm{C}), 130.8(\mathrm{CH}), 130.0(2 \mathrm{CH}), 127.1$ 
$(\mathrm{CH}), 125.7(\mathrm{CH}), 125.3(\mathrm{CH}), 118.2(2 \mathrm{CH}), 106.1(\mathrm{C}), 96.8$ (C), $59.5\left(\mathrm{CH}_{2}\right), 14.3\left(\mathrm{CH}_{3}\right)$. MS (ESI), $\mathrm{m} / z(\%)$ : calculated for $\mathrm{C}_{22} \mathrm{H}_{16} \mathrm{ClN}_{3} \mathrm{O}_{4}[\mathrm{M}]^{+} 422$, found 422 (100). Calcd: $\mathrm{C}$ 62.64; $\mathrm{H}$ 3.83; Cl 8.40; N 9.96; O 15.17. Found: $\mathrm{C}$ 62.35; H 3.71; $\mathrm{Cl} 8.29 ; \mathrm{N} 9.85$. HPLC: $\mathrm{t}_{\mathrm{r}}=1.059 \mathrm{~min}$.

2. 1. 2. General Procedure for the Synthesis Aminopyrimidine Derivatives of Naphthoquinone (3e-f)

To a magnetically stirred solution of 2,3-dichloro-1,4-naphthoquinone (1) $(0.27 \mathrm{~g}, 0.1 \mathrm{mmol})$ in DMF $(15 \mathrm{~mL})$ was added a solution of aminopyrimidine $2 \mathbf{e}-\mathbf{f}(0.1 \mathrm{mmol})$ in DMF $(10 \mathrm{~mL})$. The reaction was carried out at $65^{\circ} \mathrm{C}$ in the presence of an equivalent amount of $\mathrm{K}_{2} \mathrm{CO}_{3}$ with constant stirring for $4 \mathrm{~h}$. Reaction progress was monitored by TLC analysis. The mixture was left to cool to room temperature $\left(25^{\circ} \mathrm{C}\right)$, then the reaction mixture diluted with water $(30$ $\mathrm{ml}$ ) and acidified with $5 \% \mathrm{HCl}$ to $\mathrm{pH} 6-7$; the formed precipitate was filtered off. The precipitate was suspended in $20 \mathrm{ml}$ of ethanol, heated to boiling, filtered from impurities, the filtrate was cooled with ice to $0{ }^{\circ} \mathrm{C}$, the precipitated crystals were filtered and dried in vacuum over $\mathrm{CaCl}_{2}$ to afford compounds $\mathbf{3 a - f}$ as orange colored crystals.

2-Chloro-3-((2-(4-methyl-6-(trifluoromethyl)pyrimidin-2-yl)ethyl)amino)naphthalene-1,4-dione (3e) Yield 73\%, orange crystals, m.p. $=121-123{ }^{\circ} \mathrm{C}$. IR $(\mathrm{KBr}$, $\left.\mathrm{cm}^{-1}\right)$ : $3656(\mathrm{~N}-\mathrm{H}), 2981,2889\left(\mathrm{CH}_{\text {aliphatic }}\right), 1677(\mathrm{C}=\mathrm{O})$, 1138 (C-F). ${ }^{1} \mathrm{H}$ NMR (300 MHz, DMSO- $\left.d_{6}\right): \delta 7.91-7.99$ (m, 2H, Ar-H), 7.86-7.71 (m, 2H, Ar-H), 7.54 (br.s, NH, $1 \mathrm{H}), 4.21\left(\mathrm{t}, 2 \mathrm{H}, \mathrm{CH}_{2}\right), 3.28\left(\mathrm{t}, 2 \mathrm{H}, \mathrm{CH}_{2}\right), 2.53\left(\mathrm{~s}, 3 \mathrm{H}, \mathrm{CH}_{3}\right)$. ${ }^{13} \mathrm{C}$ NMR (75 MHz, DMSO- $\left.d_{6}\right) \delta$, ppm: $180.2(\mathrm{C}), 177.2$ (C), $168.1(\mathrm{C}), 166.7(\mathrm{C}), 149.6(\mathrm{C}), 139.5(\mathrm{C}), 133.4(\mathrm{CH})$, $133.3(\mathrm{CH}), 131.8(\mathrm{C}), 130.4(\mathrm{C}), 123.1(\mathrm{CH}), 122.7(\mathrm{CH})$, $122.0(\mathrm{C}), 112.5(\mathrm{CH}), 107.8(\mathrm{C}), 42.9\left(\mathrm{CH}_{2}\right), 31.8\left(\mathrm{CH}_{2}\right)$, $21.3\left(\mathrm{CH}_{3}\right)$. MS (ESI), $\mathrm{m} / z(\%)$ : calculated for $\mathrm{C}_{18} \mathrm{H}_{13} \mathrm{ClF}-$ ${ }_{3} \mathrm{~N}_{3} \mathrm{O}_{2}[\mathrm{M}]^{+}$395, found 395 (100). Calcd: C 54.63; H 3.30; $\mathrm{Cl}$ 8.96; F 14.40; N 10.62; O 8.09. Found: C 54.36; H 3.19; $\mathrm{Cl}$ 8.87; F 14.29 N 10.50. HPLC: $\mathrm{t}_{\mathrm{r}}=1.090 \mathrm{~min}$.

2-Chloro-3-((2-(4-(trifluoromethyl)-5,6,7,8-tetrahydroquinazolin-2-yl)ethyl)amino) naphthalene-1,4-dione (3f)

Yield 53\%, orange crystals, m.p. $=118-120^{\circ} \mathrm{C}$. IR $(\mathrm{KBr}$, $\left.\mathrm{cm}^{-1}\right): 3659(\mathrm{~N}-\mathrm{H}), 2980,2889\left(\mathrm{CH}_{\text {aliphatic }}\right), 1679(\mathrm{C}=\mathrm{O})$, 1144, 1123 (C-F). ${ }^{1} \mathrm{H}$ NMR (300 MHz, DMSO- $d_{6}$ ): $\delta$ 8.04-7.67 (m, 4H, Ar-H), 7.48 (br.s, 1H, NH), 4.19 (t, $2 \mathrm{H}$, $\left.\mathrm{CH}_{2}\right), 3.20\left(\mathrm{t}, 2 \mathrm{H}, \mathrm{CH}_{2}\right), 2.62-2.93\left(\mathrm{~m}, 4 \mathrm{H}, 2 \mathrm{CH}_{2}\right), 1.90-1.65$ $\left(\mathrm{m}, 4 \mathrm{H}, 2 \mathrm{CH}_{2}\right) .{ }^{13} \mathrm{C}$ NMR $\left(75 \mathrm{MHz}, \mathrm{DMSO}-d_{6}\right) \delta$, ppm: 180.6 (C), 177.1 (C), 168.1 (C), 165.9 (C), 153.0 (C), 139.8 (C), $133.2(\mathrm{CH}), 133.1(\mathrm{CH}), 131.3(\mathrm{C}), 130.7(\mathrm{C}), 122.8$ $(\mathrm{CH}), 122.3(\mathrm{CH}), 121.7(\mathrm{C}), 119.8(\mathrm{C}), 106.9(\mathrm{C}), 42.8$ $\left(\mathrm{CH}_{2}\right), 32.1\left(\mathrm{CH}_{2}\right), 30.8\left(\mathrm{CH}_{2}\right), 23.7\left(\mathrm{CH}_{2}\right), 22.5\left(\mathrm{CH}_{2}\right)$, $22.8\left(\mathrm{CH}_{2}\right)$. MS (ESI), $m / z(\%)$ : calculated for $\mathrm{C}_{21} \mathrm{H}_{17} \mathrm{ClF}-$ ${ }_{3} \mathrm{~N}_{3} \mathrm{O}_{2}[\mathrm{M}]^{+} 435$, found 435 (100). Calcd: C 57.87; H 3.93; $\mathrm{Cl}$ 8.13; F 13.08; N 9.65; O 7.34. Found: C 56.89; H 3.89; Cl 8.07 F 12.21; N 9.58. HPLC: $\mathrm{t}_{\mathrm{r}}=1.199 \mathrm{~min}$.

\section{2. Pharmacological Evaluation}

\section{2. 1. Animals}

Pharmacological investigations of compound 3a-f were studied using outbreed male white mice (18-22 g) as experimental animals purchased from Odessa National Medical University, Ukraine. All animals were kept under $12 \mathrm{~h} \mathrm{light}$ regime and in a standard animal facility with free access to water and food, in compliance with the European Convention for the Protection of Vertebrate Animals Used for Experimental and Other Specific Purposes (Strasbourg, 1986).

\section{2. 2. Drug Administration}

Anticonvulsant and antidepressant activities of compounds 3a-f were evaluated at $3 \mathrm{~h}$ and $24 \mathrm{~h}$ after administration. The compounds were administered orally to mice in Tween $80 /$ water emulsion at a dose of $100 \mathrm{mg} / \mathrm{kg}$ and Tween 80/water emulsion has been used as a vehicle control. Valproic acid (VPA, $400 \mathrm{mg} / \mathrm{kg}$, p.o.) and amitriptyline $(20 \mathrm{mg} / \mathrm{kg}$, p.o.) served as reference drugs, respectively.

\section{2. 3. Anticonvulsant Activity}

The anticonvulsant activity of 1,4-naphtoquinone derivatives was evaluated by pentylenetetrazole model (PTZ) as described in. ${ }^{14,15}$ Doses of PTZ for inducing clonic-tonic convulsions (DCTC) and tonic extension (DTE) were calculated relative to control. The anticonvulsant effect of compounds was estimated at $3 \mathrm{~h}$ and $24 \mathrm{~h}$ after their administration from the increase of pentylenetetrazole MED compared with a control group. MED in percent was calculated using the formula:

$$
\mathrm{MED}=\mathrm{V} / \mathrm{m} \times 10^{4}
$$

where MED - minimum effective dose of PTZ inducing DCTC or DTE; V - volume of PTZ solution, $\mathrm{ml}$; $\mathrm{m}$ - animal weight, $g$.

\section{2. 4. Antidepressant Effect}

Forced swim test (FST) was used to determine antidepressant action of 1,4-naphtoquinone derivatives 3a-f according to procedure. ${ }^{16}$ Briefly, mice were placed individually into glass cylinder filled with water $\left(24 \pm 3{ }^{\circ} \mathrm{C}\right)$ and total duration of their immobility during 5 minutes has been recorded.

\section{2. 5. Statistical Analysis}

All results are expressed as mean \pm standard error mean (SEM). One-way analysis of variance (ANOVA) was used to determine the statistical significance of the results followed by Tukey's post hoc comparison. ${ }^{* *} p<0.01$ and ${ }^{*}$ $p<0.05$ was considered as significant. 


\section{Results and Discussion}

\section{1. Chemistry}

Naphthoquinones are highly reactive compounds due to the activation of unsaturated bond by two conjugated electron-withdrawing carbonyl groups. 2,3-Dichloro-1,4-naphthoquinone readily reacts with nucleophiles with substitution of one chlorine atom by one-step mechanism. A nucleophilic attack results in the formation of $\sigma$-complex and then the chlorine anion is eliminated with the regeneration of quinoid structure. ${ }^{17,18}$ The activity of the second chlorine atom depends on the electronic effect of the first substituent. It reduces greatly when an electron-donating group such as an amine is bonded to a $\mathrm{C}_{2}$ atom. However, the second substitution can occur if electron-withdrawing substituent is introduced. ${ }^{19,20}$

Currently, minor information is available on the reaction of 2,3-dichloro-1,4-naphthoquinone with aminopyrazole derivatives. Hassan et al. ${ }^{21}$ investigated methods for the synthesis of aminopyrazole derivatives of 2,3-dichloro-1,4-naphthoquinone, 2,3-dicyano-1,4-naphthoquinone and its isomer 2-(dicyanomethylene)indan-1,3-dione. According to the described method, reaction of 2 eq. of 2,3-dichloro-1,4-naphthoquinone with 1 eq. of aminopyrazole derivatives without using a base proceeds with the formation of cyclization product involving both nucleophilic centers of 2,3-dichloro-1,4-naphthoquinone. However, in our case the aforementioned method was ineffective - only the products of monosubstitution instead of cyclization derivatives were formed and isolated with low yield after heating with triethylamine.

Given the above, synthesis of novel heterocyclic dichloronaphthoquinone derivatives (3a-f) was carried out by chlorine atom substitution of 2,3-dichloro-1,4-naphthoquinone (1) to pyrazole (3a-d) or pyrimidine (3e-f) fragments. As illustrated in Scheme 1, target compounds (3a-f) were obtained by mixing equimolar ratios of 2,3-dichloro-1,4-naphthoquinone with heterocyclic amines (2af) in ethanol with further mixture refluxing for $2 \mathrm{~h}$ in the presence of $\mathrm{Na}_{2} \mathrm{CO}_{3}$ as a base or using DMF as solvent and $\mathrm{K}_{2} \mathrm{CO}_{3}$ as a base with constant stirring of reaction mixture at $65^{\circ} \mathrm{C}$ during $4 \mathrm{~h}$.

Novel heterocyclic $\mathrm{N}$-derivatives naphthoquinone (3a-f) were obtained in the range of $42-78 \%$ yield as red or orange solids. The structures of products $\mathbf{3 a}-\mathbf{f}$ were reliably confirmed and elucidated on the basis of spectral and analytical data. The FTIR spectra exhibited absorption peaks at $3200-3659 \mathrm{~cm}^{-1}(\mathrm{NH}), 1652-1712 \mathrm{~cm}^{-1}(\mathrm{C}=\mathrm{O}), 2895-$ $2980 \mathrm{~cm}^{-1}\left(\mathrm{CH}_{\text {aliphatic }}\right), 717-720 \mathrm{~cm}^{-1}(\mathrm{C}-\mathrm{Cl})$ and 1059 $1144 \mathrm{~cm}^{-1}$ (C-F). The ${ }^{1} \mathrm{H}-\mathrm{NMR}$ spectral data of naphthoquinone 3a-f contain resonance signals described by their chemical shift, integration and multiplicity that are in full agreement with the presented molecular formulas.

\section{2. Pharmacological Studies}

In the present study, a non-competitive GABA antagonist pentylenetetrazole (PTZ) has been used to investigate anticonvulsant activity of 1,4-naphthoquinone derivatives (3a-f). PTZ-induced seizure model is positioned as a model of generalized convulsions and extensively used for evaluating the excitability of central nervous system (CNS) and, consequently, activity of gamma-aminobutyric acid (GABA). ${ }^{22}$ Valproic acid (VPA), an established antiepileptic drug possessing anticonvulsive effect on PTZ-induced model, served as reference drug. ${ }^{23}$ Anticonvulsant activity of heterocyclic compounds $\mathbf{3 a - f}$ was estimated after single oral administration $(100 \mathrm{mg} / \mathrm{kg}$, p.o.) at short (3 h) and long ( $24 \mathrm{~h}$ ) time periods. As shown in Figure 1, all synthesized compounds and VPA were found to protect animals from clonic-tonic convulsions and tonic extension at $3 \mathrm{~h}$ after their oral administration as evidenced by in-<smiles>O=C1C(Cl)=C(Cl)C(=O)c2ccccc21</smiles>

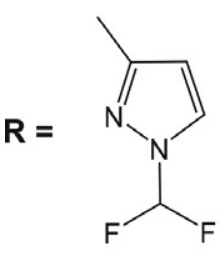

a

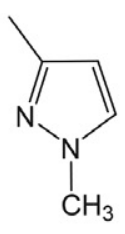

b

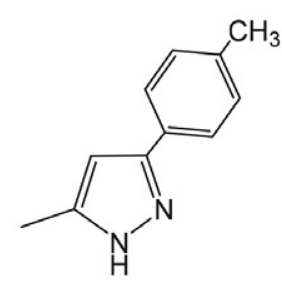

C<smiles></smiles>

3a-f

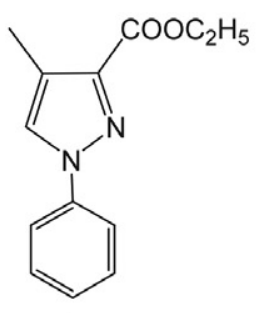

d

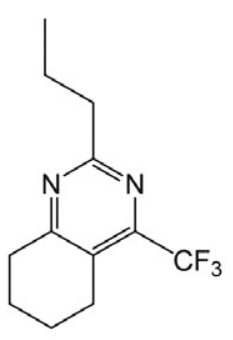

f

Scheme 1. Synthesis of aminopyrazole- (3a-d) and aminopyrimidine (3e-f) derivatives of dichloronaphthoquinone. Reagents and conditions: $\mathbf{i}$ $\mathrm{EtOH} / \mathrm{Na}_{2} \mathrm{CO}_{3}$, reflux, $2 \mathrm{~h}$; ii DMF/ $\mathrm{K}_{2} \mathrm{CO}_{3}, 65^{\circ} \mathrm{C}, 4 \mathrm{~h}$ 


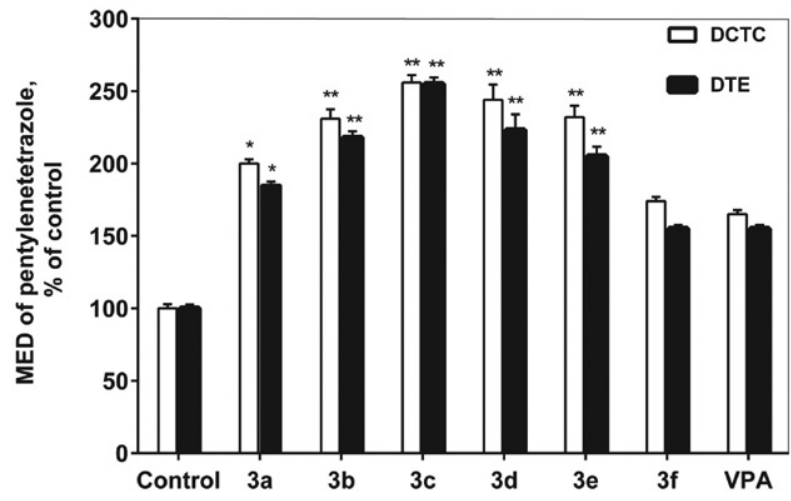

Figure 1. Anticonvulsant activity of compounds $\mathbf{3 a}-\mathbf{f}$ at $3 \mathrm{~h}$ after oral administration. Values are given as mean \pm SEM, $\mathrm{n}=5$ mice; for all groups $p<0.01$ compared with control; ${ }^{*} p<0.05$ and ${ }^{* *} p<0.01$ compared with VPA

creasing of DCTC and DTE values ( $p<0.01 v s$ control). At this time point, DCTC and DTE values of 1,4-naphthoquinones $3 \mathbf{a}(p<0.05 v s \mathrm{VPA})$ and $\mathbf{3 b} \mathbf{b}-\mathbf{e}(p<0.01 v s \mathrm{VPA})$ are statistically different from those defined for reference drug (VPA) indicating a decrease of seizure threshold.

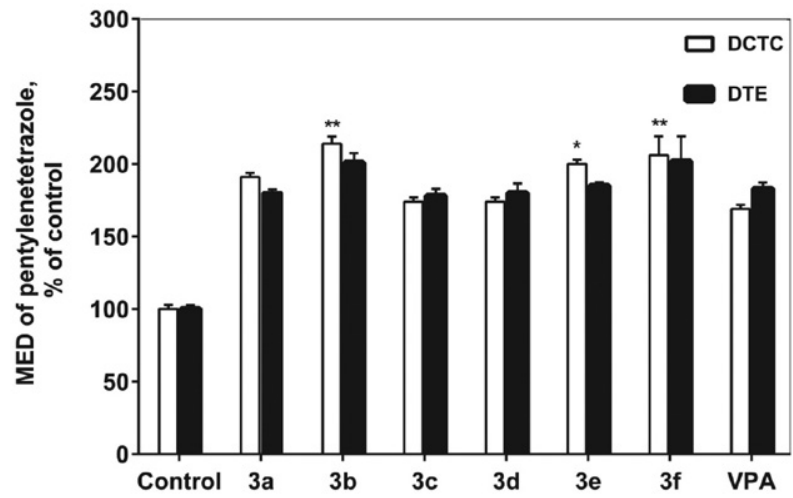

Figure 2. Anticonvulsant activity of compounds $\mathbf{3 a - f}$ at $24 \mathrm{~h}$ after oral administration. Values are given as mean \pm SEM, $\mathrm{n}=5$ mice; for all groups $p<0.01$ compared with control; ${ }^{\star} p<0.05$ and ${ }^{\star *} p<$ 0.01 compared with VPA

Evaluation of pentylenetetrazole-induced seizure susceptibility of compounds 3a-f was also carried out at long time period $(24 \mathrm{~h})$, as depicted in Figure 2. In this case, statistically significant difference was observed only in tonic phase of clonic-tonic seizures between naphthoquinones $\mathbf{3 b}(p<0.01 v s \mathrm{VPA}), 3 \mathbf{e}(p<0.05 v s \mathrm{VPA}), \mathbf{3 f}(p$ $<0.01 v s \mathrm{VPA})$ and reference drug. It is noteworthy that antiseizure effect of compounds 3a, 3c, 3d were also demonstrated prolonged anticonvulsant action at $24 \mathrm{~h}$ after administration that is indicated as DCTC and DTE increase in 2 times when compared to control.

As demonstrated in Table 1, mean immobility period was reduced in animals treated both with naphthoquinone derivatives 3a-f and reference drug amitriptyline compared to control at $3 \mathrm{~h}$ after oral administration. When compared with amitriptyline, the antidepressant activity of compounds 3a-f did not exceed that of reference drug.

Table 1. Antidepressant activity of compounds $3 \mathbf{a}-\mathbf{f}$ in forced swim test (FST).

\begin{tabular}{|c|c|c|}
\hline \multirow[t]{2}{*}{ Compound } & \multicolumn{2}{|c|}{ Immobility time, $s$} \\
\hline & $\begin{array}{c}3 \mathrm{~h} \text { after } \\
\text { administration }\end{array}$ & $\begin{array}{c}24 \mathrm{~h} \text { after } \\
\text { administration }\end{array}$ \\
\hline Control & $95.0 \pm 8.7$ & $95.0 \pm 8.7$ \\
\hline $3 a$ & $51.7 \pm 7.8$ & $34.7 \pm 4.9^{\star *}$ \\
\hline $3 b$ & $16.0 \pm 6.7$ & $39.3 \pm 8.7^{\star *}$ \\
\hline $3 c$ & $46.3 \pm 7.8$ & $53.7 \pm 3.2^{\star *}$ \\
\hline $3 \mathrm{~d}$ & $70.7 \pm 5.2$ & $20.0 \pm 4.5^{\star \star}$ \\
\hline $3 e$ & $39.0 \pm 4.4$ & $45.7 \pm 4.7^{\star *}$ \\
\hline $3 \mathrm{f}$ & $27.3 \pm 3.7$ & $47.7 \pm 3.0^{\star \star}$ \\
\hline Amitriptyline & $25.7 \pm 3.5$ & $93.7 \pm 4.4$ \\
\hline
\end{tabular}

However, there was no statistically significant difference in immobility time between control groups of animals and that treated with amitriptyline at long time period $(24 \mathrm{~h})$. At this time point, all synthesized naphthoquinone derivatives were found to possess significant antidepressant-like effect ( $p<0.01$ vs. amitriptyline) indicating a prolonged action of compounds $\mathbf{3 a - f}$.

\section{Conclusion}

Heterocyclic N-derivatives naphthoquinone containing pyrazole and pyrimidine moieties have been synthesized in good yield and characterized by a series of analytical and spectroscopic methods $\left({ }^{1} \mathrm{H}\right.$ NMR, ${ }^{13} \mathrm{C}$ NMR, FT-IR, ESI-MS, LC and elementary analysis). The activity of synthesized compounds as potential anticonvulsive and antidepressive agents was investigated on the models of PTZ-induced seizures and forced swim test (FST), accordingly. Pharmacological analyses showed that compounds 3a-f exhibit anticonvulsant and antidepressant properties at a dose $100 \mathrm{mg} / \mathrm{kg}$ both at short and long time period (3 $\mathrm{h}$ and $24 \mathrm{~h}$ after oral administration). Thus, naphthoquinone derivatives obtained at the present study demonstrate combined action on CNS and might be further studied as compounds useful for treating depressive disorders in patients with seizures.

\section{References}

1. A. K. Sharma, N. Dahiya, A. Khanapure, J. K. Kairi, Int. J. Basic Clin. Pharmacol. 2016, 5, 850-854.

DOI:10.18203/2319-2003.ijbcp20161533 
2. M. Á. Castro, A. M. Gamito, V. Tangarife-Castaño, B. Zapata, J. M. Miguel del Corral, A. C. Mesa-Arango, L. Betancur-Galvis, A. San Feliciano, Eur. J. Med. Chem. 2013, 67, 19-27.

DOI:10.1016/j.ejmech.2013.06.018

3. P. Ravichandiran, M. Masłyk, S. Sheet, M. Janeczko, D. Premnath, A. R. Kim, B. H. Park, M. K. Han, D. J. Yoo, ChemistryOpen 2019, 8, 589-600.

DOI:10.1002/open.201900077

4. I. Milackova, M. S. Prnova, M. Majekova, R. Sotnikova, M. Stasko, L. Kovacikova, S. Banerjee, M. Veverka, M. Stefek, J. Enzyme Inhib. Med. Chem. 2015, 30, 107-113.

DOI:10.3109/14756366.2014.892935

5. V. Prachayasittikul, R. Pingaew, A. Worachartcheewan, C. Nantasenamat, S. Prachayasittikul, S. Ruchirawat, V. Prachayasittikul, Eur. J. Med. Chem. 2014, 84, 247-263.

DOI:10.1016/j.ejmech.2014.07.024

6. K. Kobayashi, S. Nishiumi, M. Nishida, M. Hirai, T. Azuma, H. Yoshida, Y. Mizushina, M. Yoshida, Med. Chem. 2011, 7, 37-44. DOI:10.2174/157340611794072742

7. M. Bansal, B. Goel, S. Shukla, R. S. Srivastava, Med. Chem. Res. 2013, 22, 5349-5355.

DOI:10.1007/s00044-013-0531-6

8. D. Dhingra, S. Bansal, Pharmacol. Rep. 2015, 67, 1024-1032. DOI:10.1016/j.pharep.2015.03.001

9. W. H. Choi, S. S. Hong, S. A. Lee, X. H. Han, K. S. Lee, M. K. Lee, B. Y. Hwang, J. S. Ro, Arch. Pharm. Res. 2005, 28, 400404. DOI: $10.1007 / B F 02977668$

10. H. Zhang, S. Wang, X. Wen, J-Z. Li, Z-S. Quan, Med. Chem. Res. 2016, 25, 1287-1298.

DOI:10.1007/s00044-016-1559-1

11. K. Karrouchi, S. Radi, Y. Ramli, J. Taoufik, Y. N. Mabkhot, F. A. Al-Aizari, M. Ansar, Molecules 2018, 23, 1-86.

DOI:10.3390/molecules23010134
12. M. J. Naim, O. Alam, F. Nawaz, M. J. Alam, P. Alam, J. Pharm. Bioallied. Sci. 2016, 8, 2-17.

DOI:10.4103/0975-7406.171694

13. S. B. Wang, X. Q. Deng, Y. Zheng, Y. P. Yuan, Z. S. Quan, L. P. Guan, Eur. J. Med. Chem. 2012, 56, 139-144.

DOI:10.1016/j.ejmech.2012.08.027

14. M. V. Nesterkina, I. A. Kravchenko, Chem. Nat. Compd. 2016, 52, 237-239. DOI:10.1007/s10600-016-1604-9

15. M. V. Nesterkina, E. A. Alekseeva, I. A. Kravchenko, Pharm. Chem. J. 2014, 48, 82-84.

DOI:10.1007/s11094-014-1052-4

16. G. Gupta, T. J. Jia, L. Y. Woon, D. K. Chellappan, M. Candasamy, K. Dua, Adv. Pharmacol. Sci. 2015, 2015, 1-6. DOI:10.1155/2015/164943

17. A. A. Kutyrev, Tetrahedron 1991, 47, 8043-8065. DOI:10.1016/S0040-4020(01)91002-6

18. G.M. Neelgund, M. L. Budni, Spectrochim Acta A 2005, 61, 1729-1735. DOI:10.1016/j.saa.2004.07.003

19. M. Delarmelina, S. J. Greco, J. W. Carneiro, Tetrahedron 2017, 73, 4363-4370. DOI:10.1016/j.tet.2017.05.095

20. L. R. Domingo, J. A. Saez, R. J. Zaragoza, M. Arno, J. Org. Chem. 2008, 73, 8791-8799.

21. A. A. Hassan, N. K. Mohamed, Y. R. Ibrahim, A. F. E. Mourad, Liebigs Ann. Chem. 1993, 6, 695-697.

DOI:10.1002/jlac.1993199301112

22. A. V. Kalueff, Neurochem. Int. 2007, 50, 61-68. DOI:10.1016/j.neuint.2006.07.004

23. D. Calderón Guzmán, I. Espitia Vázquez, G. Barragán Mejía, N. Labra Ruiz, R. Rodríguez Pérez, D. Santamaria del Angel, F. Ayala Guerrero, H. Juárez Olguín, Proc. West Pharmacol. Soc. 2003, 46, 48-50.

\section{Povzetek}

Novi heterociklični derivati dikloronaftokinona so bili sintetizirani s substitucijo klorovega atoma v 2,3-dikloro-1,4-naftokinonu s fragmenti pirazola ali pirimidina. Strukture teh spojin so bile potrjene s FT-IR, ESI-MS, ${ }^{1} \mathrm{H}-\mathrm{NMR},{ }^{13} \mathrm{C}-\mathrm{NMR}$ in elementno analizo. Antikonvulzivno delovanje sintetiziranih spojin je bilo ocenjeno v pentilentetrazol (PTZ) konvulzijskem modelu in $\mathrm{z}$ antidepresivnim delovanjem $\mathrm{v}$ testu prisilnega plavanja (FST). Vsi derivati naftokinona so $\mathrm{v}$ odmerku $100 \mathrm{mg} / \mathrm{kg}$ izkazovali antikonvulzivni učinek v PTZ-induciranem testu 3 ure in 24 ur po peroralni uporabi. Poleg tega so te spojine izkazovale dolgotrajne antidepresivne lastnosti in znatno zmanjšale čas nepremičnosti v primerjavi $\mathrm{z}$ referenčno učinkovino amitriptilin.

Except when otherwise noted, articles in this journal are published under the terms and conditions of the Creative Commons Attribution 4.0 International License 